\title{
ORIGINALS
}

\section{Inhibition of Insulin and Glucagon Release from the Perfused Rat Pancreas by Cyproheptadine (Periactinol ${ }^{\circledR}$, Nuran ${ }^{\circledR}$ )*}

\author{
H. G. Joost, J. Beckmann, S. Holze, S. Lenzen, W. Poser and A. Hasselblatt \\ Institut für Pharmakologie und Toxikologie der Universität Göttingen, Geiststr. 9, Göttingen, Feđeral Republic of Germany
}

Summary. The tricyclic compound cyproheptadine $\left(\right.$ Periactinol $^{\circledR}$, Nuran $^{\circledR}$ ) inhibited glucose-induced insulin release from the perfused rat pancreas. Tolbutamide-stimulated insulin release was significantly reduced in the presence and completely suppressed in the absence of a substimulatory glucose concentration $(5 \mathrm{mM})$. Arginine produced a slow rise of insulin release, which was completely abolished by cyproheptadine. Furthermore the biphasic glucagon release due to the stimulus was inhibited. Oxidation of ${ }^{14} \mathrm{C}$ glucose in isolated islets was unaltered in the presence of cyproheptadine, and pyruvate added to the perfusion medium failed to reverse the inhibitory effect on glucose induced insulin release, indicating that impaired glucose metabolism is not responsible for the inhibition. In addition, the inhibition remained unchanged when phentolamine was present, suggesting that the effect is not mediated by inhibitory adrenergic alpha receptors. Theophylline, in contrast, partly overcame the inhibition. When the calcium concentration of the medium was enhanced, the inhibitory effect of cyproheptadine was still visible, although the relative inhibition had become smaller. The results suggest that cyproheptadine blocks insulin release by affecting a fundamental step of the stimulus-secretion coupling common to peptide hormones. A participation of a calcium-antagonizing effect in the inhibition is discussed.

Key words: Insulin release, glucagon release, cyproheptadine, tolbutamide, arginine, theophylline, calcium, perfused rat pancreas.

\footnotetext{
* The results were presented in part at the $11^{\text {th }}$ Annual Meeting of the European Association for the Study of Diabetes, Munich, September 1975 .
}

The antihistaminic-antiserotonin compound cyproheptadine [1] has been reported to produce selective B-cell abnormalities, glucose intolerance, and depletion of pancreatic insulin in rats $[2,3,4]$ when chronically administered. Acute hyperglycemia after single injections of cyproheptadine, accompanied by a decrease of plasma insulin, was observed in the rat [5] and in the Syrian hamster [6]. In addition, in vitro experiments using the perfused rat pancreas [5], isolated islets $[7,8]$, and pieces of Syrian hamster pancreas [6] revealed the inhibitory effect of cyproheptadine on insulin release.

To gain further insight into this inhibition we investigated the effects of cyproheptadine on insulin release as caused by various stimulators and effectors.

Cyproheptadine has also been reported to inhibit growth hormone (HGH) secretion $[9,10]$ and cortisol release [11], suggesting that cyproheptadine has a general inhibitory effect on hormone release. Thus we studied the effects of cyproheptadine on the arginineinduced glucagon release by the perfused rat pancreas.

\section{Materials and Methods}

\section{Chemicals}

Cyproheptadine-hydrochloride (Sharp and Dohme, München), Trasylol ${ }^{\circledR}$ (Farbwerke Bayer AG, Wuppertal-Elberfeld), tolbutamide (Hoechst AG, Frankfurt) and dextran (Knoll AG, Ludwigshafen) were obtained as gifts. Bovine albumin, pentobarbital and arginine were purchased from Serva, Heidelberg, Phentolamine (Regitin ${ }^{\circledR}$ ampoules) from Ciba AG, I-125 labelled insulin and glucagon (50-60\% immunoreactive glucagon) from Farbwerke Hoechst $\mathrm{AG}$, Frankfurt. $\mathrm{U}^{-14} \mathrm{C}$-glucose was obtained from 

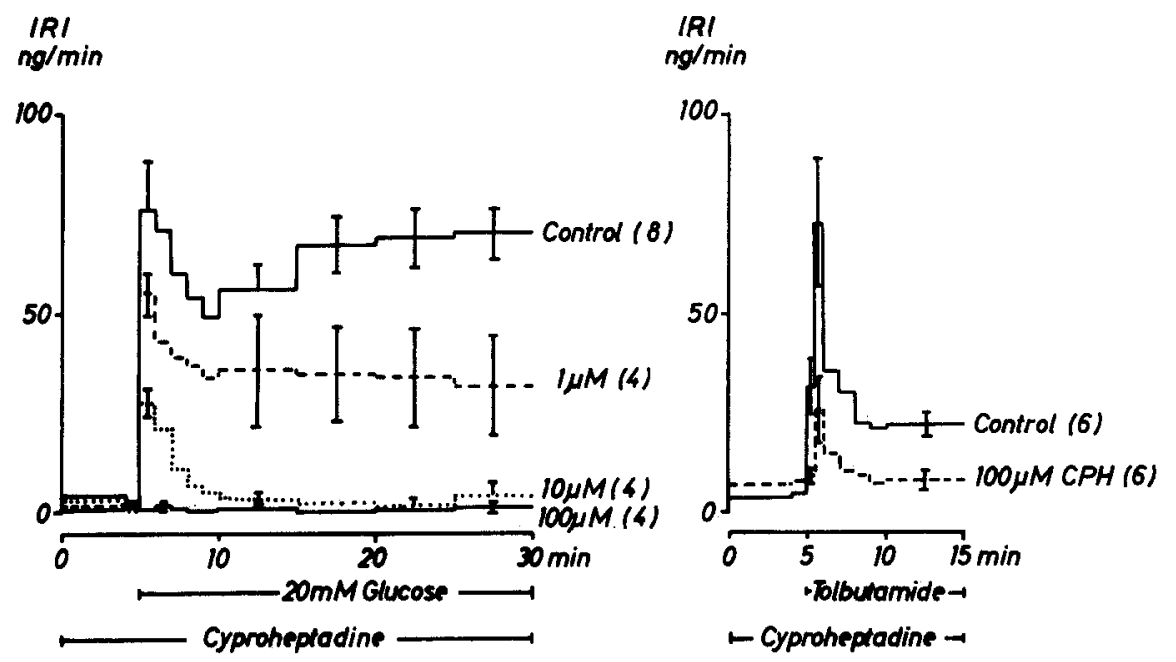

Fig. 1. Left panel: Effects of various cyproheptadine concentrations on glucose-induced $(20 \mathrm{mM})$ insulin release. Means \pm SEM of a number of experiments shown in brackets. Differences from control are significant for 10 and $100 \mu \mathrm{M}(\mathrm{p}<0.001)$ as tested by analysis of variance (Duncan's test). Right panel: Effects of $100 \mu \mathrm{M}$ cyproheptadine ( $\mathrm{CPH})$ on tolbutamide-induced $(20 \mathrm{mg} / 100 \mathrm{ml})$ insulin release in the presence of glucose $(5 \mathrm{mM})$. Means \pm SEM of a number of experiments shown in brackets. Differences from controls are significant $(\mathrm{p}<0.05)$ from $5-15$ $\min$ (U-test)
Amersham-Buchler, Braunschweig, Insta-Gel from Packard, Frankfurt. All other reagents (analytical grade) were from Merck AG, Darmstadt.

\section{Perfusion Experiments}

Male albino Wistar rats (Winkelmann, Kirchborchen) weighing 180-250 g were starved for 18-24 hours and anaesthetized by an intraperitoneal injection of pentobarbital ( $45 \mathrm{mg} / \mathrm{kg}$ body weight). Pancreas, spleen, stomach and proximal part of the duodenum were removed according to the method of Grodsky et al. [12] and perfused through the cannulated abdominal aorta. The integrity of the preparation had been confirmed by light microscopy [13]. The perfusion fluids consisted of Krebs-Henseleit buffer containing dextran $(4 \%$, average mol. weight 60000$)$ and glucose (5 $\mathrm{mM}$ ), unless higher glucose concentrations were infused as indicated. In control experiments we had ensured that lack of albumin in the medium did not reduce the secretory function. The constant flow rate $(5 \mathrm{ml} / \mathrm{min}$ ) provided a perfusion pressure of $80-100$ $\mathrm{mm} \mathrm{Hg}$. When the media were changed during the perfusion, with the aid of a valve without dead space, it took about $10 \mathrm{~s}$ until the new medium had reached the pancreas, and another $20 \mathrm{~s}$ until the perfusate was equilibrated. Immediately after collecting the perfusate in 1 or 5 minute fractions, the samples were diluted with tris-buffer ( $\mathrm{pH} 7.4$ ) containing $0.1 \%$ albumin (fraction $\mathrm{V}$, bovine albumin).

In the perfusion experiments designed to investigate glucagon release, $0.05 \mathrm{ml}$ tris-buffer containing albumin $(2 \%)$ and Trasylol ${ }^{\circledR}(400$ Units/ml) were added to $1 \mathrm{ml}$ of the perfusate and the samples were immediately frozen.

\section{Glucose Oxidation}

The oxidation of $\mathrm{U}^{1{ }^{14}} \mathrm{C}$-glucose was determined by a modification of the method of Ashcroft et al. [14]. Batches of 10 islets, isolated by collagenase digestion of mouse pancreas, were incubated for 60 minutes in $120 \mu \mathrm{l} \mathrm{Krebs-bicarbonate-buffer} \mathrm{containing} 3 \mathrm{mg} / \mathrm{ml}$ glucose (specific radioactivity: $0.25-0.75 \mathrm{mCi} / \mathrm{mM}$ ). The $U-{ }^{14} \mathrm{C}$-glucose had been purified from carbonatelike-activities by ion exchange chromatography. ${ }^{14} \mathrm{CO}_{2}$ was trapped in $1 \mathrm{ml} 0.1 \mathrm{M} \mathrm{NaOH}$ and counted in $9 \mathrm{ml}$ Insta-Gel. After subtraction of blanks obtained by incubations without islets the results were calculated as pmol glucose per islet per $h$.

\section{Insulin and Glucagon Determinations}

Insulin and glucagon were measured radioimmunologically [15] using antibodies prepared in our laboratory. Glucagon-antisera were obtained from rabbits according to the method of Frohman et al. [16]. The buffers used throughout the glucagon assay contained Trasylol ${ }^{\circledR}(200$ Units $/ \mathrm{ml})$ in order to prevent the breakdown of glucagon during the incubation period. Separation of the bound and free fraction was achieved with cellulose according to Zaharko and Beck [15].

\section{Calculations}

The results are calculated as means \pm SEM and differences of the release rates at each time interval were tested for statistical significance with the U-test of Wilcoxon, Mann and Whitney. As stated, pooled data were compared by analysis of variance (Duncan's test). 

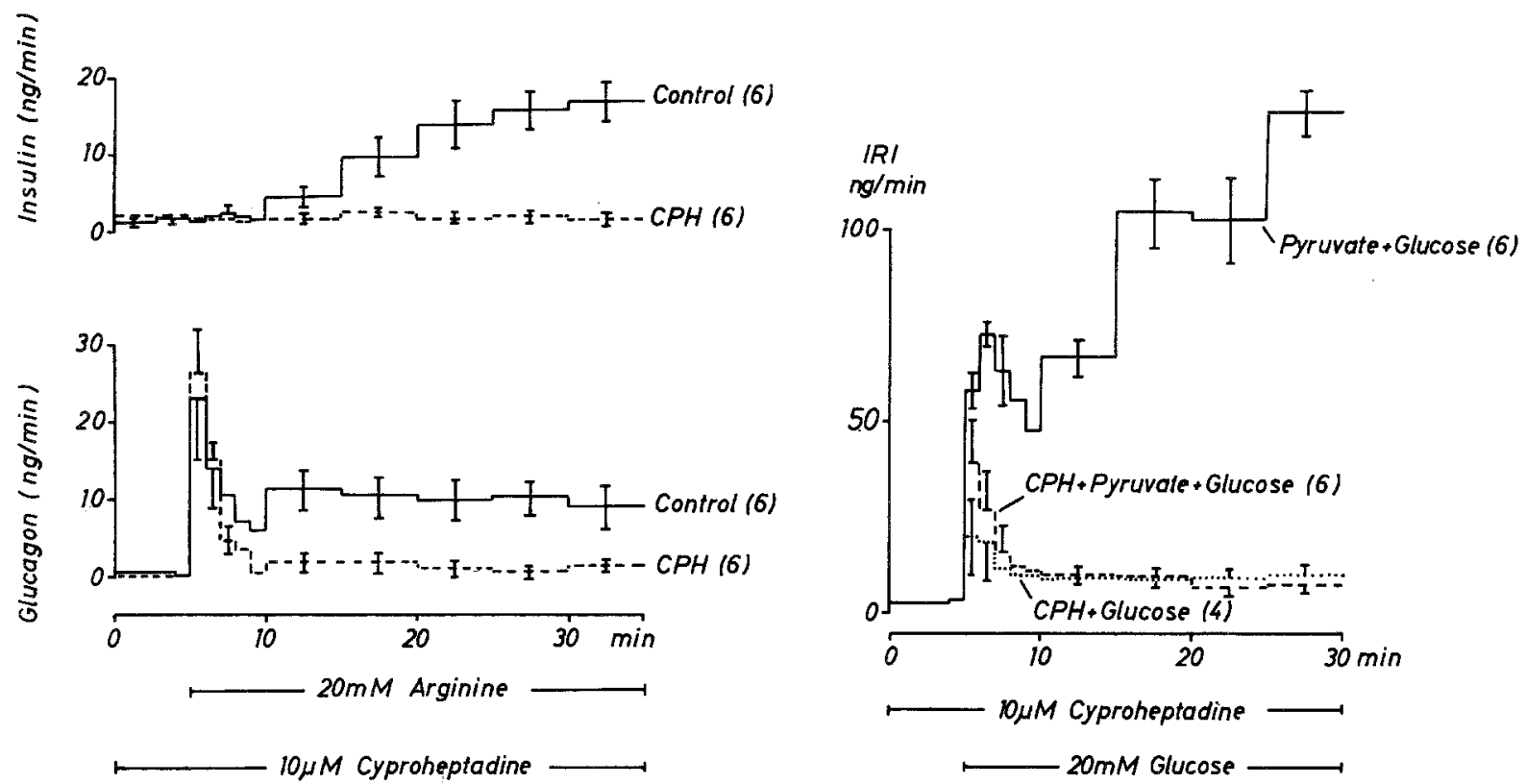

Fig. 2. Effects of $10 \mu \mathrm{M}$ cyproheptadine on arginine-induced (20 $\mathrm{mM}$ ) insulin and glucagon release. The media contained no basal glucose. Means \pm SEM. Differences from controls are significant from $15-35 \mathrm{~min}(\mathrm{p}<0.01)$ for insulin, from $10-35 \mathrm{~min}(\mathrm{p}<0.025)$ for glucagon (U-test)

\section{Results}

Cyproheptadine infused 5 min prior to the stimulus significantly inhibited the typical biphasic secretory response to a high-glucose load (Fig. 1, left panel). Even the very small concentration of $1 \mu \mathrm{M}$ produced a weak inhibition, whereas $100 \mu \mathrm{M}$ cyproheptadine completely abolished both phases. In the presence of $10 \mu \mathrm{M}$ cyproheptadine the initial peak was less affected than the late phase.

Tolbutamide elicited a single peak of insulin release even in the absence of glucose. This stimulatory effect was inhibited by cyproheptadine when the perfusion media contained $5 \mathrm{mM}$ glucose (Fig. 1, right panel), and completely abolished in the absence of glucose (data not shown).

Arginine is known to produce a different secretion pattern from that of glucose and tolbutamide [17]. In our experiments cyproheptadine completely blocked this slowly ascending insulin release (Fig. 2). Simultaneously the release of immunoreactive glucagon (IRG) was inhibited (Fig. 2).

$10 \mu \mathrm{M}$ cyproheptadine inhibited the second phase of the biphasic IRG-release produced by arginine ( 20 $\mathrm{mM}$ ), while the initial peak remained unaffected. The tenfold concentration $(100 \mu \mathrm{M})$, however, reduced the glucagon output during the immediate secretory response (data not shown).

Fig. 3. Failure of pyruvate $(10 \mathrm{mM})$ to alter the inhibitory effect of cyproheptadine. Means \pm SEM

Glucose-oxidation by incubated islets was increased fivefold in the presence of the high glucose stimulus compared to basal conditions. Cyproheptadine did not affect glucose oxidation when high glucose was present: islets oxidized $25.6 \pm 3$ pmol glucose per islet per hour (control) vs. $26.6 \pm 4$ and 26.3 \pm 4 pmol in the presence of 100 and $10 \mu \mathrm{M}$ cyproheptadine, respectively.

Pyruvate $(10 \mathrm{mM})$ infused together with the high glucose load did not alter the inhibitory effect of cyproheptadine (Fig. 3). Furthermore, phentolamine $(0.02 \mathrm{mM})$ apparently did not reverse the inhibition (Fig. 4).

Theophylline (10 mM), in contrast, enhanced the insulin release of the pancreas exposed to both cyproheptadine and glucose (Fig. 5). The inhibitory effect of cyproheptadine, however, was not completely reversed, although the first phase appeared to be largely restored.

Table 1 gives the results obtained in the presence of various calcium concentrations. When the media contained $10 \mu \mathrm{M}$ cyproheptadine, in the presence of 5 and $7.5 \mathrm{mM}$ calcium more insulin was released than at normal $(2.5 \mathrm{mM})$ or reduced $(1 \mathrm{mM})$ calcium levels. The inhibitory effect of cyproheptadine was still significant, however, as compared to the corresponding controls, and although the relative inhibition was smaller, the differences have not been reduced by high calcium. 


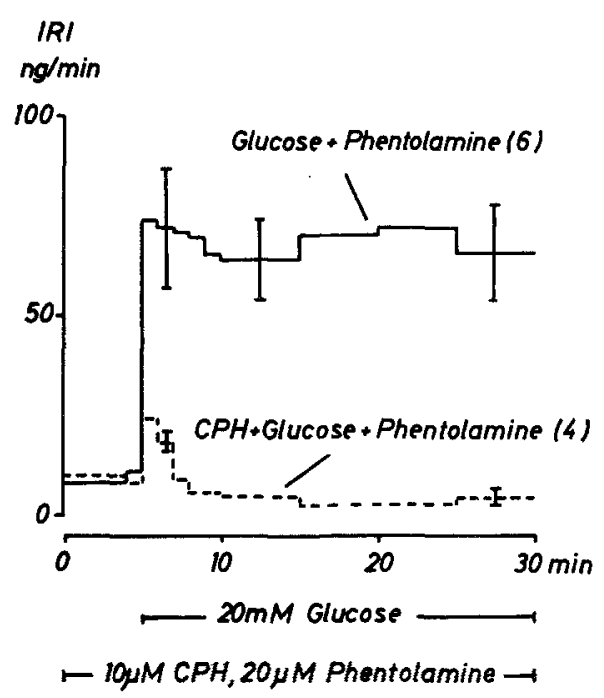

Fig. 4. Failure of phentolamine $(20 \mu \mathrm{M})$ to reverse the inhibitory effect of cyproheptadine on insulin release. Means \pm SEM. Differences are significant $(\mathrm{p}<0.01)$ from $5-30 \mathrm{~min}(\mathrm{U}$-test)

\section{Discussion}

The inhibitory effect of cyproheptadine on insulin release in vivo after prolonged treatment $[2,3]$ or single injections [5], and in vitro $[5,6,7,8]$ has been well established. Our results confirm that cyproheptadine is a very potent inhibitor of glucose-induced insulin release, since the low concentration of $1 \mu \mathrm{M}$ was still effective.

The inhibitory effect is not restricted to the glucose-induced secretory response but includes tolbutamide- and arginine-stimulated secretion. Since the three stimulators produce different secretion patterns, they are supposed to trigger insulin release via different mechanisms. In addition, Rickert and Fischer [18] previously reported that the stimulatory effect of tolbutamide, leucine, dibutyryl-cyclic-AMP, and glucagon on incubated pieces of rat pancreas was reduced, when the animals had been pretreated with cyproheptadine. These results concerning different stimuli suggest that cyproheptadine blocks a basic link in the secretion process. The hypothesis is supported by the finding that cyproheptadine reduced arginineinduced glucagon release. In addition, cyproheptadine is known to diminish the secretion of human growth hormone and cortisol $[9,10,11]$. Thus a gen-

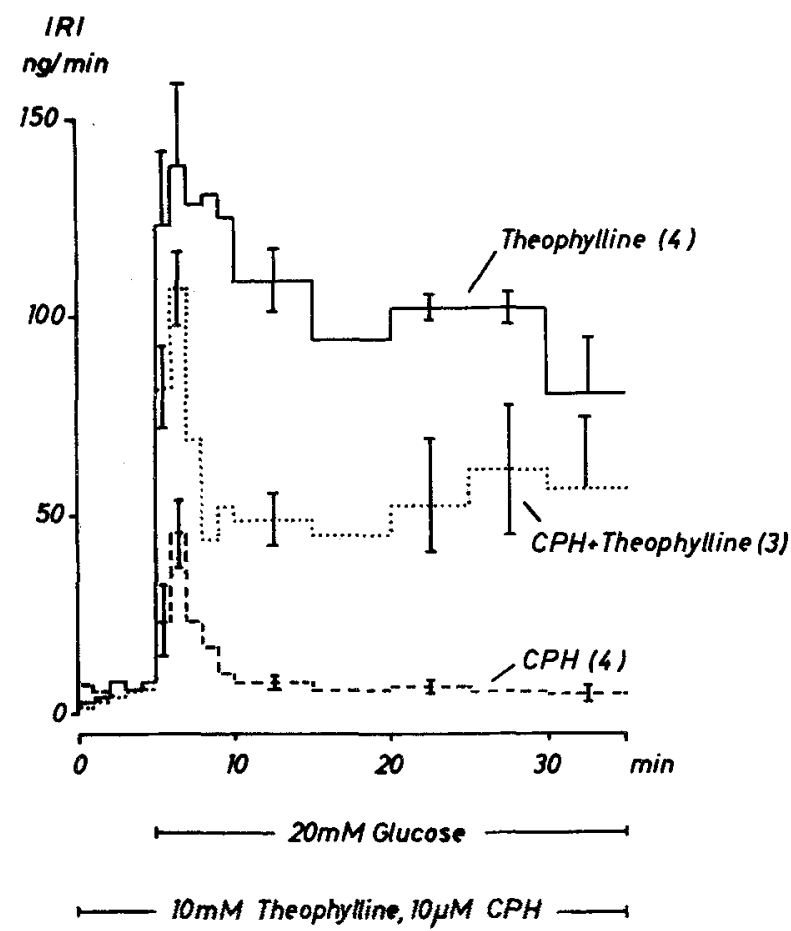

Fig. 5. Effects of a theophylline-infusion ( $10 \mathrm{mM})$ on the inhibitory action of cyproheptadine $(10 \mu \mathrm{M})$. Means \pm SEM. The differences are significant $(\mathrm{p}<0.01)$ as tested by analysis of variance (Duncan's test)

eral property to inhibit hormone release may be attributed to the agent.

A prominent effect of cyproheptadine is its antagonism of serotonin. Insulin release is controlled by serotonin, if at all, not in a stimulatory but in an inhibitory way [19]. Thus it is unlikely that insulin release is reduced by cyproheptadine via the serotonin-antagonizing effect of the agent.

Phentolamine was infused, together with cyproheptadine, in order to elucidate whether cyproheptadine acts via adrenergic alpha receptors, but this agent failed to reduce the inhibitory effect of cyproheptadine. Feldman et al. [6] observed that the enzyme monoamine oxidase was inhibited by cyproheptadine and attributed the inhibition of insulin release to this effect. In view of our experiments it is unlikely that direct or indirect effects of cyproheptadine on adrenergic alpha receptors at the B-cell cause the inhibition of insulin release. If cyproheptadine increased the serotonin, one would expect that the agent itself antagonized the elevated levels.

The inhibitory effects of iodoacetate [20] and thyroxine treatment [21] on insulin release can almost completely be reversed by pyruvate. Since pyruvate may serve as a source of metabolic energy which is utilized independently from glycolysis, these findings 
Table 1. Inhibitory effect of cyproheptadine $(10 \mu \mathrm{M})$ on glucose-induced $(20 \mathrm{mM})$ insulin release from the perfused rat pancreas in the presence of various calcium concentrations. After a 15 min infusion of glucose, cyproheptadine was added for another $25 \mathrm{~min}$. The insulin released within the last $15 \mathrm{~min}$ of this period was summed up and calculated as means $\pm S E M . N=4$. Differences to control experiments are significant $(\mathrm{P}<0.025, \mathrm{U}$-test $)$

\begin{tabular}{lcl}
\hline Calcium $(\mathrm{mM})$ & \multicolumn{2}{l}{ Insulin release $(\mathrm{ng} / 15 \mathrm{~min})$} \\
\cline { 2 - 3 } & Cyproheptadine & Control \\
\hline 1 & $30 \pm 7$ & $208 \pm 50$ \\
2.5 & $84 \pm 9$ & $357 \pm 69$ \\
5 & $300 \pm 50$ & $708 \pm 30$ \\
7.5 & $320 \pm 33$ & $523 \pm 50$ \\
\hline
\end{tabular}

were supposed to reflect a specific interference with glucose metabolism [21]. Infused together with glucose and cyproheptadine, pyruvate failed to restore the normal secretory response. Glucose metabolism, as estimated from the production of ${ }^{14} \mathrm{CO}_{2}$, was not affected by cyproheptadine. These results indicate that a specific block of glucose utilization is not responsible for the observed inhibition.

Although cyclic AMP probably does not mediate glucose induced insulin release [22], it is widely accepted that the nucleotide potentiates the effects of glucose and other stimulators [23]. Thus the potentiating effect of theophylline on glucose-induced insulin release may be mediated by an increase of the intracellular cyclic AMP [24], which in turn was supposed to translocate calcium from organelle-bound pools to the cytoplasm [25]. In addition, theophylline has recently been reported to produce a rise of cyclic AMP levels and a short increase of insulin release independently from extracellular calcium [26]. The xanthine derivative may, however, also have effects in addition to inhibition of the phosphodiesterase, particularly if concentrations as high as $10 \mathrm{mM}$ are applied. In our experiments theophylline $(10 \mathrm{mM})$ partly reversed the inhibitory effect of cyproheptadine. Thus the islet is not refractory to every stimulus and insulin is apparently still available. If one assumes that theophylline increases the cytosol calcium concentration - mediated by cyclic AMP or independently from cyclic AMP - this increase affected the inhibition but did not completely reverse it.

Calcium ions are an essential requirement for insulin release [27]. It has been suggested, therefore, that the cytosol calcium concentration initially triggers the secretory process [28], and, more precisely, that exocytosis of the negatively charged granules is facilitated by calcium [29]. Our recent finding that cyproheptadine reduced the accumulation of calcium-45 in incubated mouse islets [30] prompted experiments with enhanced calcium concentration of the medium in order to reverse the inhibition. Consistent with the recently reported results of Hellman [31], calcium enhanced the secretory response to glucose, and, at still higher concentration, decreased it. Because of these complex effects of calcium the interpretation of the data obtained in the presence of cyproheptadine is difficult. The results suggest that the inhibitory action of cyproheptadine is affected by calcium, although not in a competitive manner, since the secretion was not fully restored to normal. Provided that the observed inhibition results from a disturbed calcium metabolism of the B-cell [30], the antagonism between cyproheptadine and calcium is non-competitive.

Acknowledgement. The authors are indebted to Miss B. Berning and Miss U. Reimer for excellent technical assistance. The investigations were supported by the Deutsche Forschungsgemeinschaft.

\section{References}

1. Stone, C.A., Wenger, H.C., Ludden, C.T., Stavorski, J.M., Ross, C.A.: Antiserotonin-antihistaminic properties of cyproheptadine. J. Pharmacol. exp. Ther. 131, 73-84 (1961)

2. Longnecker, D.S., Wold, J.S., Fischer, L.J.: Ultrastructural alterations in B-cells of pancreatic islets from cyproheptadine treated rats. Diabetes 21, 71-79 (1972)

3. Wold, J. S., Longnecker, D.S., Fischer, L. J.: Species dependent pancreatic islet toxicity produced by cyproheptadine: Alteration in beta cell structure and function. Toxicol. appl. Pharmacol. 19, 188-201 (1971)

4. Rickert, D.E., Burke, J., Fischer, L. J.: Cyproheptadine-induced depletion of insulin in the rat. J. Pharmacol. exp. Ther. 193, 585-593 (1975)

5. Joost, H. G., Poser, W., Panten, U.: Inhibition of insulin release from the rat pancreas by cyproheptadine and tricyclic antidepressants. Naunyn-Schmiedeberg's Arch. Pharmacol. 285, 99-102 (1974)

6. Feldman, J.M., Chapman, B.A., Plonk, J.W.: Monoamine oxidase inhibition: Possible mechanism for cyproheptadine-induced alterations in insulin secretion. Life Sci. 15, 1121-1134 (1974)

7. Joost, H.G., Beckmann, J.: Inhibition of insulin release by cyproheptadine in vitro. Naunyn-Schmiedeberg's Arch. Pharmacol. 287, R 59 (1975)

8. Richardson, B.P., McDaniel, M.L., Lacy, P. E.: Effects of cyproheptadine on insulin secretion by isolated perifused rat islets. Diabetes 24, 836-841 (1975)

9. Bivens, C.H., Lebovitz, H.E., Feldman, J.M.: Inhibition of hypoglycemia-induced growth hormone secretion by the serotonin antagonists cyproheptadine and methysergide. New Engl. J. Med. 289, 236-239 (1973)

10. Nakai, Y., Imura, H., Sakurai, H., Kurahachi, H., Yoshimi, T.: Effect of cyproheptadine on human growth hormone secretion. J. clin. Endocr. 38, 446-449 (1974)

11. Plonk, J. W., Bivens, C. H., Feldman, J. M.: Inhibition of hypoglycemia-induced cortisol secretion by the serotonin antagonist cyproheptadine. J. clin. Endocr. 38, 836-840 (1974) 
12. Grodsky, G. M., Batts, A. A., Bennett, L. L., Vcella, C., McWilliams, N. B., Smith, D.F.: Effects of carbohydrates on secretion of insulin from isolated rat pancreas. Amer. J. Physiol. 205, 638-644 (1963)

13. Klöppel, G.: Personal communication

14. Ashcroft, J.H., Hedeskov, C.J., Randle, P.J.: Glucose metabolism in mouse pancreatic islets. Biochem. J. 118, 143-154 (1970)

15. Zaharko, D.S., Beck, L.V.: Studies of a simplified plasma insulin immunoassay using cellulose powder. Diabetes 17, 444-457 (1968)

16. Frohman, L.A., Reichlin, M., Sokal, J.E.: Immunologic and biologic properties of antibodies to a glucagon-serum albumin polymer. Endocrinology 87, 1055-1061 (1970)

17. Gerich, J.E., Charles, M. A., Grodsky, G. M.: Characterization of the effects of arginine and glucose on glucagon and insulin release from the perfused rat pancreas. J. clin. Invest. 54, 833-841 (1974)

18. Rickert, D.E., Fischer, L. J.: Cyproheptadine and betacell function in the rat: Insulin secretion from pancreas segments in vitro. Proc. Soc. exp. Biol. (N.Y.) 150, 1-6 (1975)

19. Lernmark, A.: The significance of 5-hydroxytryptamine for insulin secretion in the mouse. Horm. Metab. Res. 3, 305-309 (1971)

20. Matschinsky, F.M., Ellerman, J.: Dissociation of the insulin releasing and the metabolic functions of hexoses in islets of Langerhans. Biochem. biophys. Res. Commun. 50, 193-199 (1973)

21. Lenzen, S., Panten, U., Hasselblatt, A.: Thyroxine treatment and insulin secretion in the rat. Diabetologia 11, 49-55 (1975)

22. Hellman, B., Idahl, L. A., Lernmark, A., Täljedal, I.B.: The pancreatic $\beta$-cell recognition of insulin secretagogues: Does cyclic AMP mediate the effect of glucose? Proc. nat. Acad. Sci. (Wash.) 71, 3405-3409(1974)

23. Cooper, R.H., Ashcroft, S.J.H., Randle, P.J.: Concentration of adenosine-3' $5^{\prime}$-cyclic monophosphate in mouse pancreatic islets measured by a protein-binding radioassay. Biochem. $\mathbf{J}$. 134, 599-605 (1973)
24. Kuo, W.N., Hodkins, D. S., Kuo, J.F.: Regulation by various hormones and agents of adenosine-3', 5'-monophosphate levels of islets of Langerhans in rats. Biochem. Pharmacol. 23, 1387-1391 (1974)

25. Brisson, G.R., Malaisse-Lagae, F., Malaisse, W.J.: The stimulus-secretion coupling of glucose-induced insulin release VII. A proposed site of action for adenosine-3', 5'-cyclicmonophosphate. J. clin. Invest. 51, 232-241(1972)

26. Charles, M. A., Lawecki, J., Pictet, R., Grodsky, G. M.: Insulin secretion. Interrelationships of glucose, cyclic adenosine 3'-5'-monophosphate, and calcium. J. biol. Chem. 250, 6134-6140 (1975)

27. Curry, D. L., Bennett, L.L., Grodsky, G.M.: Requirement for calcium ion in insulin secretion by the perfused rat pancreas. Amer. J. Physiol. 214, 174-178 (1968)

28. Malaisse, W.J., Pipeleers, D. G., Mahy, M.: The stimulus-secretion coupling of glucose-induced insulin release XII. Effects of diazoxide and gliclazide upon ${ }^{45}$ calcium efflux from perifused islets. Diabetologia 9, 1-5 (1973)

29. Matthews, E.K., Evans, R.J., Dean, P.M.: The ionogenic nature of the secretory-granule membrane. Biochem. J. 130, $825-832$ (1972)

30. Joost, H. G., Beckmann, J., Lenzen, S., Hasselblatt, A.: Inhibition of insulin release by cyproheptadine: Effects on $3^{\prime}, 5^{\prime}$-cyclic-AMP-content and ${ }^{45} \mathrm{Ca}$-accumulation of incubated mouse islets. Acta endocr. (Kbh.). (in press 1976)

31. Hellman, B.: The significance of calcium for glucose stimulation of insulin release. Endocrinology 97, 392-398 (1975)

Received: August 21, 1975, and in revised form: February 12, 1976

Dr. H.G. Joost

Institut für Pharmakologie

und Toxikologie der Universität

Geiststraße 9

D-3400 Göttingen

Federal Republic of Germany 